\title{
Horror przemocy wobec dzieci wczoraj i dziś
}

\author{
Golus, A. (2019). Dzieciństwo w cieniu rózgi. Historia i oblicza \\ przemocy wobec dzieci. Gliwice: Helion.
}

\begin{abstract}
Abstrakt:
W artykule recenzyjnym omówiono monografię Anny Golus pt. Dzieciństwo w cieniu rózgi. Historia i oblicza przemocy wobec dzieci (2019). Jego celem jest nakreślenie historii, kontekstu kulturowego oraz stanu obecnego przemocy stosowanej wobec dzieci i młodych ludzi w odniesieniu zarówno do obowiązujących regulacji prawnych w tym zakresie, jak i dyskusji społecznych związanych z poruszonymi kwestiami. W końcowej części artykułu analizie zostają poddane szczególnie te wątki książki Golus, w których autorka ujawnia afektywne nastawienie do prezentowanego tematu przemocy wobec dzieci. Mimo prawnego zakazu bywa ona bowiem w XXI wieku w Polsce propagowana pod postacią pozornie niewinnych kar, takich jak klaps czy „karny jeżyk”.
\end{abstract}

Słowa kluczowe:

Anna Golus, czarna pedagogika, dziecko, przemoc wobec dzieci, studia nad dziećmi i dzieciństwem

\section{Horror of Violence Against Children Yesterday and Today}

\section{Abstract:}

The review article discusses a monograph by Anna Golus, Dziecinstwo $w$ cieniu rózgi. Historia i oblicza przemocy wobec dzieci [Childhood in the Shadow of a Rod: The History and Faces of Violence against Children] (2019). Its purpose is to outline the history, cultural context of violence towards children and young people, as well as its current state, both in relation to applicable legal regulations in this area

* Ewelina Rąbkowska - dr, kieruje Muzeum Książki Dziecięcej (działem specjalnym Biblioteki Publicznej m.st. Warszawy - Biblioteki Głównej Województwa Mazowieckiego). Jej zainteresowania naukowe obejmują literaturę dziecięcą i młodzieżową, powieści wspomnieniowe oraz kulturowe studia nad zwierzętami. Kontakt: ewelina.rabkowska@365.koszykowa.pl. 
and social discussions related to the presented issues. In the final part of the article, those fragments of the book by Golus are analysed in which the author reveals her affective attitude towards the topic of violence against children. Despite the legal ban, some forms of seemingly innocent punishments, such as a smack or time-out, are sometimes propagated in Poland in the $21^{\text {st }}$ century.

Key words:

Anna Golus, black pedagogy, child, violence against children, children and childhood studies

\title{
Wprowadzenie
}

\begin{abstract}
Ana Golus (2019) jako autorka publikacji Dzieciństwo w cieniu rózgi. A Historia i oblicza przemocy wobec dzieci występuje w podwójnej roli. $\mathrm{Z}$ jednej strony, jest badaczką podejmującą studia, które przyporządkować można obszarowi children and childhood studies, czyli studiom nad dziećmi i dzieciństwem, z drugiej jednak strony - to aktywistka, propagatorka praw dziecka, publicystka (Golus zainicjowała m.in. kampanię „Kocham. Nie daję klapsów” i akcję „Książki nie do bicia”; b.a., b.d.). Właśnie to podwójne ukierunkowanie autorki Dzieciństwa w cieniu rózgi warunkuje charakter recenzowanej publikacji jako książki popularnonaukowej poświęconej historii przemocy wobec dzieci oraz jako głosu propagującego prawny zakaz stosowania owej przemocy.
\end{abstract}

\section{Pochodzenie i formy przemocy wobec dzieci}

Autorka w wielu rozdziałach książki nakreśla historyczne przejawy przemocy wobec dzieci. Już pierwszy, otwierający rozdział - W powijakach - przedstawia szokujący i na pewno przez wielu już dziś zapomniany zwyczaj spowijania potomstwa. Czynność ta polegała na ciasnym owijaniu niemowląt w pasy materiału tak, żeby nie mogły się ruszać. Krępowanie owo, pomyślane jako forma prewencji urazów, a mające źródło w dużej mierze w pseudomedycznych przesądach, było w istocie, co podkreśla Golus (2019, s. 6-7), wyrafinowaną formą znęcania się nad noworodkami. Powijaki, stosowane wbrew naturalnej we wczesnym rozwoju potrzebie ruchu, a także wbrew higienie, częstokroć dla wygody opiekunów nie były bowiem wymieniane tygodniami. Wrzynające się w skórę dziecka pasy materiału, przesycone moczem oraz ekskrementami, powodowały zakażenia i niejednokrotnie przyczyniały się do śmierci spowitego 
niemowlęcia. Dopiero lata krytyki tego zwyczaju przez postępowych pedagogów przyczyniły się do stopniowego odchodzenia od niego.

Kolejne rozdziały publikacji przynoszą wiele dobrze osadzonych w źródłach faktów na temat różnych form przemocy w stosunku do dzieci. Dla doby antyku charakterystyczne było dzieciobójstwo. Golus (2019, s. 33) pisze, że dopiero w IV wieku n.e. zniesiono przysługujące ojcu prawo decydowania o życiu i śmierci potomka. Z kolei aż do XIII wieku powszechną praktyką społeczną było porzucanie dzieci, a wieki od XIV do XVIII to czas ambiwalentnego stosunku przejawianego przez ludzi dorosłych względem małoletnich. Pisze o tym w słynnej publikacji na temat historii dzieciństwa Philip Ariés (1960/1995, s. 9), którego tezę, jakoby brak troski i miłości rodzicielskiej wobec dzieci przejawiał się aż do XVIII wieku, przytacza Golus. W momencie, gdy dorośli zdali sobie $\mathrm{z}$ całą mocą sprawę ze specyfiki okresu dziecięcego, rodzicielstwo $\mathrm{z}$ ambiwalentnego stało się „natrętne, intruzywne” (Golus, 2019, s. 32). To wtedy właśnie nasiliły się przemoc wobec dzieci, stosowana $\mathrm{z}$ rozmysłem jako narzędzie wychowania i zbawienia, a także molestowanie seksualne nieletnich, powodowane nieuświadomionymi żądzami dorosłych. Zmiany w funkcjonowaniu nowożytnej rodziny, wartościowanie dziecka nie ze względów ekonomicznych (tania siła robocza), ale ze względów emocjonalnych (potomek rodu, spadkobierca majątku i statusu) - doprowadziły do tego, że rodzice zaczęli pokładać w potomkach własne ambicje na przyszłość, a co za tym idzie - postrzegać ich jako inwestycję. W XIX i pierwszej połowie XX wieku słabnie presja socjalizacji dzieci poprzez terror oraz bicie, tym samym staliśmy się świadkami - od drugiej połowy XX wieku - rodzicielstwa wspierającego, pomocnego (s. 32-40).

Golus wiąże przemoc wobec dzieci z brutalną przeszłością wielu cywilizacji, kiedy to kary cielesne były stosowane wobec wszystkich i zapisane w prawie. Chłosta, ćwiartowanie, piętnowanie rozpalonym żelazem, łamanie na kole, kamienowanie, a nawet ukrzyżowanie czy palenie na stosie - to tylko nieliczne przykłady, które w powszechnej świadomości do dziś są łączone z rozmaitymi rodzajami przemocy wobec różnych grup społecznych. Formy przemocy, również w stosunku do dzieci, są zatem warunkowane kulturowo. Golus zauważa, przytaczając badania Bronisława Malinowskiego (1910-1914/2002) nad Aborygenami australijskimi, że kultury pierwotne były łagodne dla małoletnich. Podobnie rzecz się miała z kulturą np. Indian z plemienia Arapaho, gdzie kara cielesna wobec dzieci nie występowała (Golus, 2019, s. 21). Na ten idealny obraz społeczności pierwotnych nakłada się, co zresztą słusznie zauważa autorka recenzowanego opracowania, zwyczaj rytualnej inicjacji młodzieży, w różnych jego formach oraz przejawach, który częstokroć nosił cechy przemocy fizycznej oraz psychicznej (s. 23-28). Badaczka nie pominęła także takich form przemocy, jak 
np. obrzezanie chłopców czy też wycinanie części narządów płciowych u dziewcząt, praktykowanych jeszcze do dziś w kilku regionach świata, a wywodzących się z prastarych zwyczajów okaleczania. Zatem, jak Golus pokazuje w rozprawie, nie ma kultury wolnej od chociażby symbolicznej przemocy wobec dzieci i mimo że intencjonalne bicie potomstwa za karę jest wynalazkiem kultury Zachodu (s. 21), to wiele jej form było ukrytych w pierwotnych zwyczajach.

\section{„Złota rószczka"}

Rózga, jako „zdobycz” naszej kultury i „niezawodne” narzędzie wychowania młodego pokolenia, była nieodłącznym atrybutem dorosłych zarówno w domach, jak i szkołach. Jej używanie traktowano jako coś „naturalnego”, a konieczność oraz dobroczynność działania tego przyrządu uzasadniano przede wszystkim cytatami z Biblii, a także z pism i nauk ojców Kościoła, filozofów oraz pierwszych pedagogów. Golus (2019) zwraca uwagę, że propagowano nawet pojęcie „wieku rószczkowego” , który „kończy się u dziewczynek po szóstym roku życia, a u chłopców - nie wiadomo kiedy" (s. 63). W rozdziałach Nie kocha syna, kto rózgi żałuje oraz Biblijna rózga wXXI wieku autorka recenzowanej rozprawy analizuje treść wielu tekstów kierowanych do wychowawców i rodziców, utwierdzających ich w przekonaniu o konieczności stosowania rózgi i „boskim” charakterze tego aktu.

Warto w tym miejscu przywołać tytuł powstałej w XIX wieku książki z wierszami dla dzieci, autorstwa Heinricha Hoffmanna (1845), która w Polsce znana jest właśnie pod tytułem Złota rószczka, chociaż jej oryginalny tytuł brzmi Der Struwwelpeter. W kolejnych wierszach wchodzących w skład tego zbiorku - widać to w polskiej adaptacji (Hoffmann, 1892/2018) - przedstawiane są dziecięce wady oraz przewiny na przykładzie konkretnych bohaterów, a także kary, jakie spadają na owe dzieci, włącznie ze śmiercią - jako konsekwencją złego postępowania. Oczywiście w dzisiejszych dyskusjach nad tą publikacją podkreśla się, że być może już w czasach powstania nie mogła ona być traktowana poważnie i stanowi raczej przejaw absurdalnego humoru, a przedstawione kary mają charakter umowny i stanowią zabawę konwencją, którą dziecko rozumie i chętnie podejmuje (Lebecka, 2002, s. 151). Nawet gdyby przyznać temu stanowisku rację, dowodziłoby ono istnienia wcześniejszej tradycji pisarstwa dla niedorosłych ukazującego groźbę kar cielesnych lub nawet śmierci dziecka za złe postępowanie bez humorystycznego mówienia nie wprost. Polscy XIX-wieczni pisarze tworzący dla dzieci i młodzieży, np. Stanisław Jachowicz, Klementyna z Tańskich Hoffmanowa czy Maria Konopnicka, 
opisywali raczej łagodne kary wymierzane niesfornym dziecięcym bohaterom, zsyłane na te postaci przez los, a nie rękę rodzicielską, jednak w ich utworach nie było miejsca na absurdalny humor czy zabawę konwencją. Złe postępki dziecięcych postaci w literaturze dla niedorosłego czytelnika musiały spotkać się z karą. W omawianej publikacji teksty literackie dla dzieci nie były przedmiotem namysłu autorki, ale choćby zasygnalizowanie tego wątku pozwoliłoby na wzbogacenie przedstawionej refleksji badawczej o ciekawe wnioski.

Najcenniejszym poznawczo wątkiem książki Golus jest analiza statusu cielesnego karania dzieci w XXI wieku. Wbrew konsensusowi prawnemu w wielu krajach Zachodu, które przyjęły prawny zakaz stosowania takich kar wobec dzieci, pewne kręgi, szczególnie powiązane z grupami wyznaniowymi, wciąż propagują ich wykonywanie. Golus zajmuje się tutaj wyłącznie przypadkiem Polski, gdzie w latach 90. XX wieku i w XXI wieku tłumaczone oraz wznawiane były publikacje $\mathrm{z}$ tzw. pasa biblijnego w Stanach Zjednoczonych. Autorka wymienia i analizuje pięć tytułów (Barnes, 1990/2010; Chase, 1999/2006; Fugate, 1980/2008; Pearl, Pearl, 1994/2010; Smalley, 1983/2006), które ukazały się na rodzimym rynku wydawniczym (nowe tłumaczenia i reedycje) w latach 2006-2010 i zawierają zachętę oraz instruktarz stosowania kar cielesnych nawet wobec niemowląt. Omawiane przez Golus pozycje zawierają szokujące opisy fizycznego i psychicznego znęcania się nad dziećmi. Autorka trafnie interpretuje je jako świadectwa m.in. porażek wychowawczych, bezradności dorosłych jako rodziców, nieprzygotowania do tej roli, niedojrzałości psychicznej oraz dewiacji sadystycznych i pedofilskich wykazywanych przez dorosłych (często autorów tychże książek), które - szczególnie te ostatnie, $\mathrm{w}$ formie projekcji własnych popędów seksualnych - skutkują przyzwoleniem na bicie małoletnich. Nieuświadomione podłoże seksualne ma zwłaszcza bicie nagich dzieci. Badaczka, definiując w ten sposób ów proceder, odsłania jego prawdziwe oblicze, odziera ze znaczeń, które próbuje mu się nadać - z postrzegania jako chwalebne i wielce skuteczne narzędzie wychowania dzieci w duchu pokory, posłuszeństwa, poszanowania woli starszych.

Golus przytacza również przykład słynnego i popularnego w Polsce programu Superniania, emitowanego w latach 2006-2008, w czasie najwyższej oglądalności w niedzielne popołudnie. Prowadząca program, Dorota Zawadzka, propagowała wśród rodziców karę polegającą na czasowej izolacji dziecka, pieszczotliwie nazwaną „karnym jeżykiem” (Grupa TVN, 2006-2008). Tej formie przemocy psychicznej czasami towarzyszyło też naruszenie nietykalności cielesnej dziecka, które nie chciało się takiej karze poddać (ciągnięcie za rękę do miejsca izolacji, sadzanie na siłę). Badaczka pokazuje, że często pozornie niewinnie wyglądające działania rodziców są wedle prawa formą przemocy. 
Gdyby np. „karny jeżyk” miał być stosowany w zakładach pracy wobec pracowników, byłby uznany za formę mobbingu.

Publikacja Golus jest tym bardziej znacząca, że próby sprzedaży książek propagujących klapsy czy lanie są wciąż podejmowane, nie wiemy więc, czego można się spodziewać w przyszłości w tym zakresie. Warto wspomnieć, że stosunkowo niedawno Magdalena Komsta (2020) na fanpage’u Wymagające.pl na portalu Facebook zamieściła post w sprawie wydania książki Pasterz serca dziecka Tedda Trippa (2009), w której promuje się bicie dzieci (w tym niemowląt) za karę. Po interwencji czytelników wydawnictwo Słowo Prawdy zawiesiło sprzedaż tej pozycji.

\section{Dzieci i zwierzęta - wspólnota wykluczonych}

Autorka zamyka swe rozważania, przedstawiając zmianę $\mathrm{w}$ poparciu dorosłych dla stosowania kar cielesnych wobec dzieci w Polsce. Dane liczbowe zaprezentowane przez Golus (2018, s. 190-197) potwierdzają to, że w XXI wieku wzrosła świadomość szkodliwości klapsa czy lania. Coraz mniej ludzi przyznaje się $\mathrm{w}$ ankietach, że takie metody stosuje albo popiera. To, że bicie małoletnich wyrządza nieodwracalne szkody w odniesieniu do zarówno poszczególnych dzieci, jak i całych społeczeństw, w których jest ono stosowane, wynika m.in. z szeroko rozpowszechnionych prac Alice Miller (1978/1995, 1980/1999, 1981/1991). Publikacje tej badaczki Golus przytacza w kontekście studiowania tzw. czarnej pedagogiki. Jest to nurt psychologii dziecka zapoczątkowany przez tę znaną psycholożkę badający wpływ przemocy psychicznej na umysł dziecka. Miller, a za nią Golus (2019), powtarzała tezę, że „bici biją tych, którzy będą bić" (s. 165). Brutalność i okrucieństwo kumulują się z pokolenia na pokolenie, a ich pokłosiem jest przemoc w skali społecznej (np. wojna). Istnieje powszechna zgoda także polskich badaczy co do tego, że krzywda wyrządzona w dzieciństwie odciska się piętnem na całym dorosłym życiu ofiary. Zagadnieniom tym poświęcone zostało czasopismo Dziecko Krzywdzone. Teoria, Badania, Praktyka, gdzie opublikowano wiele artykułów na ten temat (np. Dragan, 2018; Klecka, Palicka, 2018; Pastwa-Wojciechowska, Izdebska, 2016).

Bardzo ciekawie prezentuje się rozdział, w którego tytule autorka recenzowanej książki buduje analogię pomiędzy rozwojem praw dzieci i zwierząt. Jednak poza stwierdzeniem, że ruch ochrony praw nieletnich niejako wywodzi się z wcześniej rozwijanego ruchu na rzecz ochrony praw kobiet oraz zwierząt, zabrakło w tym rozdziale pogłębionej analizy form i przyczyn przemocy wobec zwierząt oraz analogii statusu dzieci i zwierząt domowych w nowożytnej rodzinie. 
Pogłębienie badań o refleksje Ariésa (1960/1995), Érica Barataya (2012/2014), a przede wszystkim Janusza Korczaka (1919/1984) pozwoliłoby na sformułowanie ciekawych wniosków. Zauważają oni bowiem podstawową wspólnotę statusów zwierząt oraz dzieci. Wykluczenie we wszelkim szowinizmie, także w odniesieniu do małoletnich, polega na tym, że stygmatyzuje się podmiot poprzez wskazywanie na jego zwierzęce cechy (Roudinesco, 2001/2015). W tę samą logikę wykluczenia wpisuje się myślenie na przestrzeni dziejów o dziecku jako istocie bardziej „Zwierzęcej” niż dorosły (Kehily, 2004/2008, s. 20-21).

Namysł nad dzieckiem jako istotą podmiotową i sprawczą pojawił się dopiero w nurcie filozofii dzieciństwa i pedagogiki wolnościowej na przełomie XIX oraz XX wieku. Korczak, korzystając bardzo często z analogii „dziecko” - „Zwierzę”, obnażał pułapkę kategoryzowania niedorosłej istoty ludzkiej jako niegotowego, niedoskonałego, a więc jakby „zwierzęcego” bytu. Stary Doktor z całą mocą postulował uznanie podmiotowości dziecka od jego narodzin. Walczył z zasadą, zgodnie z którą proces wychowawczy musi oznaczać uznanie „zwierzęcości” małoletniego człowieka i przybierać formę kwarantanny, zamknięcia jednostki do czasu osiągnięcia przez nią pełni człowieczeństwa w imię zasady: „Moje dziecko to moja własność, mój niewolnik, mój psiak pokojowy” (Korczak, 1919/1984, s. 138). Tymczasem - jak pisał - dziecko „jest człowiekiem, a nie pinczerkiem na atłasowej poduszce" (s. 184). Natomiast inną sprawą jest, że polski pisarz i pedagog przypisywał dziecku niezwykłą wrażliwość na zwierzęcy los. Rozumie ono bowiem, jak sądził, że niejako podziela dolę i status zwierząt w świecie dorosłych i że jest to solidarność niewolników - istot słabszych.

\section{Zakończenie}

Książka Golus jest publikacją nie tylko o charakterze poznawczym, lecz także interwencyjnym. Dobrze udokumentowane i zanalizowane źródła historyczne oraz oblicza przemocy wobec dzieci stanowią podstawę ustaleń o charakterze etycznym, psychologicznym i prawnym. Odczuwa się osobiste zaangażowanie autorki w przedstawiany temat, co jest charakterystyczne dla nowoczesnych nurtów badawczych. Przy czym, co trzeba dodać, monografia nie jest hermetyczna, a wręcz przeciwnie - napisana przystępnym językiem, ma szansę trafić do szerokiego grona odbiorców i przyczynić się do wzrostu świadomości na temat bicia dzieci. Na pewno stanowi ona wyraźną przeciwwagę dla wspomnianych wcześniej publikacji promujących bicie, które mogą wciąż docierać do rodziców i wychowawców. 


\section{Bibliografia}

Ariés, P. (1995). Historia dzieciństwa. Dziecko i rodzina w dawnych czasach (M. Ochab, tłum.). Gdańsk: Marabut. (wyd. oryg. 1960).

b.a. (b.d.). Anna Golus [biogram]. Tygodnik Powszechny. Pobrane z: https://www.tygodnikpowszechny.pl/autor/anna-golus- 685 .

Baratay, É. (2014). Zwierzęcy punkt widzenia. Inna wersja historii (P. Tarasewicz, tłum.). Gdańsk: Wydawnictwo w Podwórku. (wyd. oryg. 2012).

Barnes, R. (2010). I kto tu rządzi? Poradnik dla sfrustrowanych rodziców (G. Ciecieląg, tłum.). Warszawa: Oficyna Wydawnicza Vocatio. (wyd. oryg. 1990).

Chase, B. N. (2006). Mądra miłość. Jak wychowywać dzieci, ucząc je odpowiedzialności (M. Stiff, tłum.). Warszawa: Oficyna Wydawnicza Vocatio. (wyd. oryg. 1999).

Dragan, M. (2018). Zaburzenia psychiczne u dorosłych krzywdzonych w dzieciństwie - badanie z zastosowaniem wywiadu strukturalizowanego SCID-I. Dziecko Krzywdzone. Teoria, Badania, Praktyka, 17(2), 9-25.

Fugate, R. (2008). Wychowanie dziecka wedtug Pisma Świętego (M. Stiff, A. Gandecki, tłum.). Lublin: Pojednanie. (wyd. oryg. 1980).

Golus, A. (2019). Dzieciństwo w cieniu rózgi. Historia i oblicza przemocy wobec dzieci. Gliwice: Helion.

Grupa TVN. (2006-2008). Superniania [program telewizyjny]. Warszawa: TVN.

Hoffmann, H. (1845). Der Struwwelpeter oder lustige Geschichten und drollige Bilder für Kinder von 3-6 Jahren von Dr. Heinrich Hoffmann. Frankfurt am Main: Literarische Anstalt.

Hoffmann, H. (2018). Złota rószczka. Czytajcie dzieci, uczcie się, jak to niegrzecznym bywa źle. Wydanie trzecie (W. Szymanowski, tłum.). Warszawa: Graf_ika. (wyd. oryg. 1892).

Kehily, M. J. (2008). Zrozumieć dzieciństwo. Wprowadzenie w kluczowe tematy i zagadnienia. W: M. J. Kehily (red.), Wprowadzenie do badań nad dzieciństwem (M. Kościelniak, tłum., s. 15-40). Kraków: WAM. (wyd. oryg. 2004).

Klecka, M., Palicka, I. (2018). Trauma rozwojowa u dzieci - perspektywa neurorozwojowa. Dziecko Krzywdzone. Teoria, Badania, Praktyka, 17(2), 26-37.

Komsta, M. (2020, 22 stycznia). Co mam zrobić tym razem? [post opublikowany na portalu Facebook]. Pobrane z: https://www.facebook.com/wymagajace/ posts/1841291432670788.

Korczak, J. (1984). Jak kochać dziecko. W: Pisma wybrane (t. 1, s. 89-382). Warszawa: Nasza Księgarnia. (wyd. oryg. 1919).

Lebecka, H. (2002). Hoffmann Heinrich. W: B. Tylicka, G. Leszczyński (red.), Słownik literatury dziecięcej i młodzieżowej (s. 151-152). Wrocław, Warszawa, Kraków: Zakład Narodowy im. Ossolińskich.

Malinowski, B. (2002). Aborygeni australijscy. Socjologiczne studium rodziny $i$ inne prace przedterenowe. Warszawa: WN PWN. (wyd. oryg. 1910-1914). 
Miller, A. (1991). Mury milczenia. Cena wyparcia urazów dzieciństwa (J. Hockuba, tłum.). Warszawa: WN PWN. (wyd. oryg. 1981).

Miller, A. (1995). Dramat udanego dziecka. Studia nad powrotem do prawdziwego Ja (N. Szymańska, tłum.). Warszawa: Jacek Santorski \& CO. (wyd. oryg. 1978).

Miller A. (1999). Zniewolone dzieciństwo. Ukryte źródła tyranii (B. Przybyłowska, tłum.). Poznań: Media Rodzina. (wyd. oryg. 1980).

Pastwa-Wojciechowska, B., Izdebska, A. (2016). Zdarzenia traumatyczne w okresie dzieciństwa a rozwój osobowości psychopatycznej u osób skazanych. Dziecko Krzywdzone. Teoria, Badania, Praktyka, 15(2), 73-92.

Pearl, D., Pearl, M. (2010). Jak trenować dziecko? (G. Grygiel, tłum.). Warszawa: Oficyna Wydawnicza Vocatio. (wyd. oryg. 1994).

Roudinesco, É. (2015). Przemoc wobec zwierząt. Rozmowa z J. Derridą (B. Brzezicka, tłum.). Znak, 720, 34-43. (wyd. oryg. 2001).

Smalley, G. (2006). Klucz do serca twojego dziecka (R. Jankowski, tłum.). Lublin: Pojednanie. (wyd. oryg. 1983).

Tripp, T. (2009). Pasterz serca dziecka (b.t.). Warszawa: Słowo Prawdy. (wyd. oryg. 1995). 